\title{
THE SYMBOLIC MEANING OF THE TRADITIONAL ROOF IN THE HOUSES OF KARO NORTH SUMATERA, INDONESIA
}

\author{
Erwin Ardianto Halim ${ }^{1}$, Tessa Eka Darmayanti ${ }^{1,2}$ and Citra Amelia ${ }^{1}$ \\ ${ }^{1}$ Interior Department, Faculty of Arts and Design - Maranatha Christian University, Indonesia \\ ${ }^{2}$ School of Housing, Building \& Planning, Universiti Sains Malaysia, Malaysia
}

\begin{abstract}
The aesthetic elements of traditional house of Karo are divided into three parts. They consist of upper part, middle part, and lower part. This article explains about Gerga Siwaluh Jabu as Karo's Traditional House, in Desa Lingga, North Sumatera, Indonesia. This article focuses on the roof as the upper part of the house. The roof has the historical, social and cultural background. The ornaments attached on the roof have some important roles in Karo's community. The aim of this qualitative research is to encourage the awareness about the meaning beyond the symbols used in Karo's house. Cultural study approaches were used in this research as well as that of the tradition aesthetic theory. The article provides different perspective towards the historical and traditional artifact as the cultural identity. Not only serve its aesthetic purpose, those aesthetic elements on the Karo's house roof are also seen as the protector of the inhabitants.
\end{abstract}

Keywords: Aesthetic Elements, Traditional House, Karo, Gerga Siwaluh Jabu, Culture

\section{Introduction of Karo's Traditional House}

Indonesia is an archipelago country, located at the world's strategic place, and has become a place where western and eastern cultures interacts. It is highly probable for Indonesia to be an entrance gate for foreign countries to enter and pass on their cultures and their beliefs as well. Those legacies then enrich Indonesian cultural values. The newest problems Indonesia has been facing - especially in younger generations are cultures, crisis, identity crisis, and cultural roots crisis. Many ways can be implemented to cope with those problems. As scholars, one of the methods is to conduct some research about Indonesian cultures. Indonesian cultures that interest the researchers is Karo ethnic's culture, one of the ethnic located in the northern side of Sumatera Island, Indonesia. This ethnic is indigenous tribes of highland mountain areas like Berastagi and Kabanjahe.

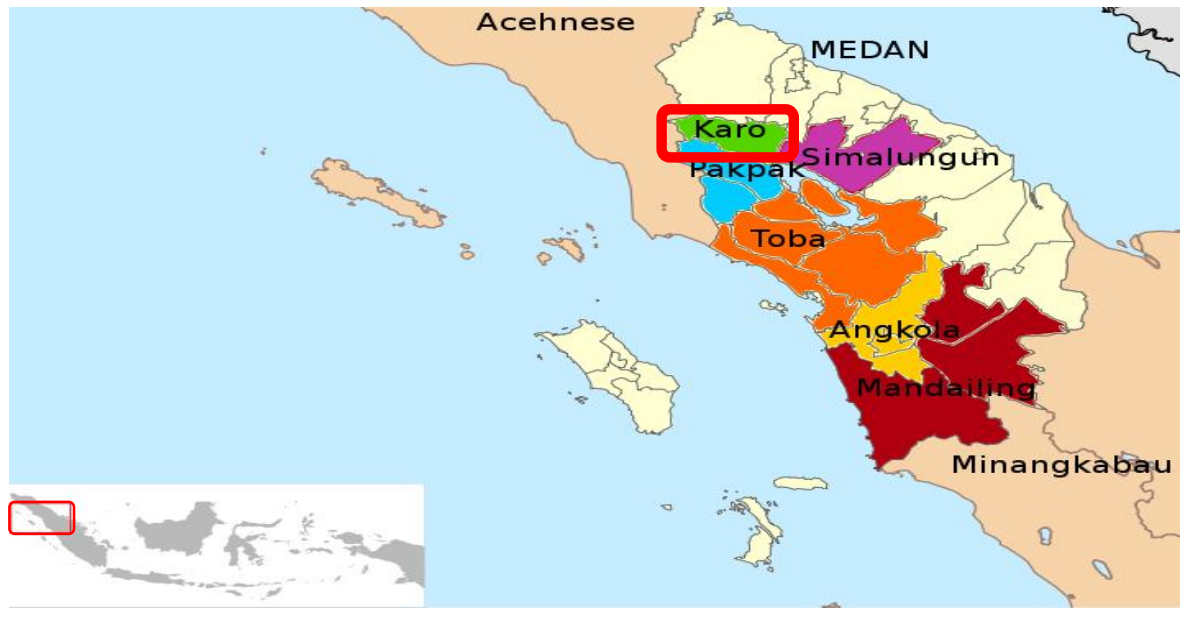

Figure 1 Location Map of Karo District

Corresponding Authors’ Emails: 'halim.rwin@gmail.com, ${ }^{2}$ tessaeka82@gmail.com, ${ }^{3}$ citra.amelia8@gmail.com 
The most important element from Karo ethnic is their traditional house. The traditional house is not only functioning as a place to take shelter from the weather, but also has a deeper meaning. This house is divided into three components; namely the top part that includes the roof, middle part--called as the body-- where all the activities take place, and last the bottom part of the house. All of the house components have their own meaning that relates to Karo community traditional life. Those meanings were born from several aesthetic elements which can be found at the three Karo traditional house components. However, to limit the study,this article focuses on its roof component.

At the beginning, Karo tribe lived in a small size houses. Its shape was simpler and could only be inhabited by one family; this house was called barung-barung. The house construction was based on the teamwork nature and the activity is mainly initiated by Sangkep Sitelu (sukut, kalimbubu and anak beru) assisted by Anak Kuta (local village community). Karo people believe that traditional house is where the ancestral spirits reside. Therefore, to build a traditional house is the same as to build a "house" of spirits. Rituals must be performed before the construction of the house to it's finished. The earliest ritual process was that people deliberate ceremony called Runggu to determine the right day to begin the construction. That day, a ritual of laying down the house foundation will be performed. The ritual aims to inquire for protection from the Karo ancestor so that the construction process of the house is protected from danger. When the house has been completed, the people will immediately performe a ritual of Mengket Rumah Mbaru, which means to enter into a new house. This ritual is intended as a gratitude to the ancestors as well as a plead for survival in the harmonious and full of blessings living. Their lives were based on mutual interest and unity for the defense from wild beasts and attacks from the outside threat. As time went by, the community is growing larger, and small houses are increasing in numbers, creating the desire to build a bigger and stronger house to accommodate several families (Fauzi, 2013; B.A Simanjuntak, 2015). The direction of Karo house is built based on the direction kenjahe (downstream) and kenjulu (upstream) in line with the village's water flow. Bigger and stronger house will make them feel comfortable and secure. A traditional house is a common property, not only intended for a single family. Its ownership consists of children beru, senina and kalimbubu. Each part of the custom house or called jabu-jabu is designed according to its position and function.

Karo traditional house is inhabited by eight families, yet the kitchen in the house is only four. That is why each jabu is divided into two, making it into jabu-jabu Sedapuren Bena Kayu, Sedapuren ujung Kayu, Sedapuren lepar Bena Kayu and Jabu Sedapuren Lepar Ujung Kayu. The wood material used to build the Karo Traditional House consists of 3 types, namely Ndrasi wood, which functions to keep family members from diseases; Ambartuah which is believed to bring the family gets into a livelihood or welfare life; and Sibernaik wood, which aims to obtain the ease of livelihood.

The traditional house is usually divided into three parts, which are:

- Top area (the house top part: roof), representing the God

- Middle area (the house body), representing the human world

- Upper area (the house basement), representing the underwold 


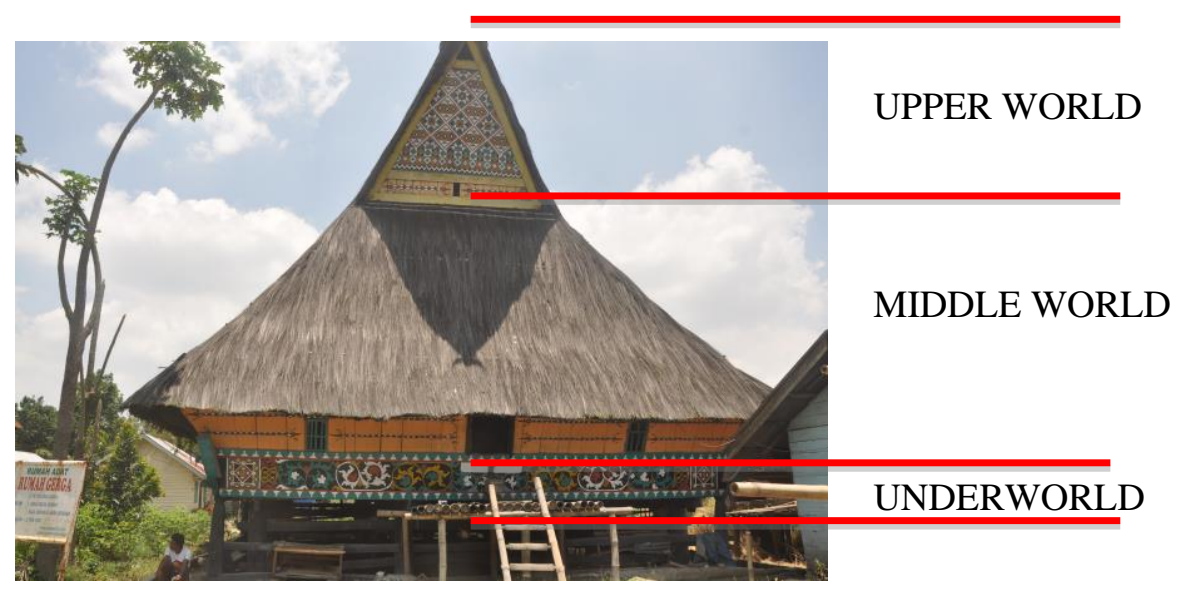

Figure 2 the Parts of Karo Traditional House

\section{Research Methodology}

This paper is developed through a literature review and the process of identifying the research focus was based on a survey regarding the research site. The survey was intended to investigate the facts in Desa Lingga, Kabupaten Kabanjahe, Karo, North Sumatera. The researchers have started to collect the data since 2016. The researchers met local people, as the first informant, named Mr.Tersek Ginting. He is the generation of his family who lives in Desa Lingga. In addition to interview method, in order to obtain specific data required, this research will implement the collection of visual documentation in detail during the field research. This qualitative paper applies tradition aesthetic theory in order to improve the understanding on the topic and issues. Tradition aesthetic or known as estetika tradisi relates closely to tradition-based aesthetic ideologies. In this case, the theory of "Pattern or Pola" by Jakob Sumardjo (2014) was used. The definition of this theory of Pattern shall be described in the following section. The major issue is to bring forward the symbolic meaning of Karo traditional house's roof aesthetic element.

\section{Research Background}

Decorative or aesthetic elements contained in the roof of Karo traditional houses has cultural and traditional value. As a preliminary knowledge, essentially, the aesthetic element is the arrangement of decorative patterns using decorative motifs in certain ways and rules in a space or plane so as to produce an attractive and beautiful shape. Decorative variety consists of two components, namely decorative patterns and decorative motifs. Decorative pattern is a basic element that is often used as a reference in making decorative design. Meanwhile, decorative motif is the basic form and the main idea in the manifestation of the ornamental variety, covering all the natural forms of God's creation such as animals, plants, people, mountains, water, clouds, rocks, and those that are under the creation of human beings. The aesthetic element is generally depicted repeatedly in order to fill the empty space. The depiction may be in the form of stilation of an object.

The traditional aesthetic elements motif utilize many geometric elements such as curved and straight lines, circles, triangles, quadrangles, meander forms, and swastika, which is symbols or ornaments with a cross-like shape and crossword cross-angles. Swastika is interpreted as a symbol of the universe circulation, as well as the sun and a gyre form. This decoration was originally made with strokes following the shape of a decorated object. In its development, this motif can be applied to various places in a building using various techniques, namely painted, drawn, carved, or printed. Karo traditional house's roof motif are made with hand drawing and painted techniques.

According to Jakob Sumardjo (2014), the ornament meaning can be traced on the basis of its local culture. There are basic "patterns" of the various aesthetic elements possessed by various cultures in Indonesia, from 
pattern one, also known as pola satu, to pattern five or pola lima based on their cultural artifacts and arts from every ethnicity. These patterns can lead to the significance embodied in it so that it indirectly discovers the "identity" of particular traditional society. Aesthetic or ornamental elements in cultures generally appear as a boost of aesthetic needs along with other traditional knowledge. In the Karo community, in addition to the aesthetic needs, the kinship system and belief system are the most influential aspects of the traditional house presence, which can be seen in more details in the presence of various aesthetic motifs in the house building components. Both systems evolve to form social order that become the cultural basis of the Karo community. There are several variations of ornaments that have the objective of repelling the evil spirits or as a treatments medium by Guru Mbelin. However in other variations, many ornaments serve as symbols of the beliefs, ideals, and worldview of a society (Kriswanto Ginting, 2014).

\section{Discussion of Karo Traditional House Roof's Aesthetic Elements}

The aesthetic element at the triangular facade part of the Karo traditional house roof's is called Ayo-Ayo, with the buffalo horns placed at the top of the roof. Aesthetic element in Karo traditional house, the Ayo-Ayo part of the roof, is a variation of geometric motifs and a combination of five distinctive Karo's colors namely black, green, red, yellow and white. The combination of motifs and colors has an important role in symbol meaning. Based on the observation, the researchers see that the repetition arrangements of geometric shapes can form horizontal or vertical lines. (figure 3)

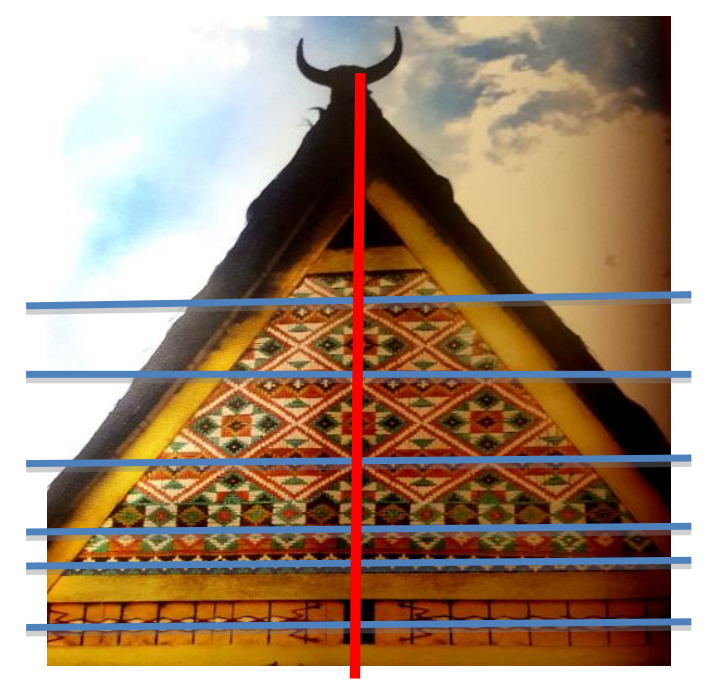

Figure 3. Horizontal and Vertical Lines at Ayo-ayo's Karo Traditional House

Horizontal and vertical lines created from geometric motifs arrangements are divided into five patterns. The first pattern arrangement forms a horizontal line symbolizing human life. The interpretation is supported by dominant red color application. The red color is a representation of the middle world in which all living creatures live and interact in it, including humans. The rhombic motif has three colors, representing the 'layers' of Karo community's world belief which are the Upper World and the Under World (figure 4). 


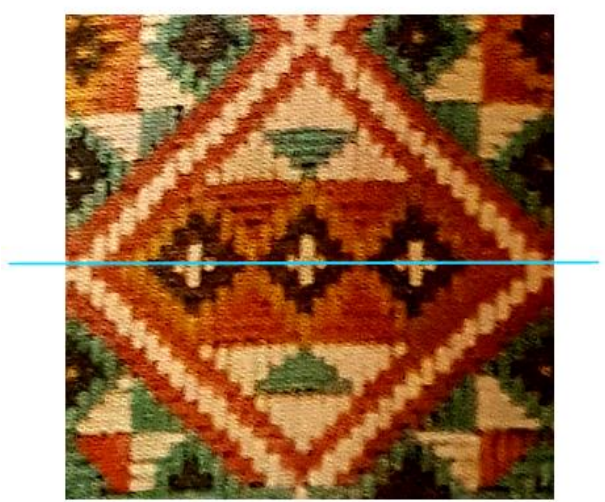

Figure 4. First Pattern at Ayo-Ayo's Karo Traditional Roof

The second and fifth patterns are the same motifs that are the stilation of the Gundur flowers, but there is little difference in the middle of color arrangement pattern (figure $5 \& 6$ ). Gundur Flower is a type flora ornament which uses natural plant forms as the decoration form. Gundur Flower functions as misfortunes repellent. The depiction of flora ornaments in ornamental art is done by various techniques; both natural and artistic in accordance with the artists' desire and the types of plants which became the inspiration. Additionally, it may differ depending on the environment (nature, social, and beliefs at a certain time) where the pattern was created.

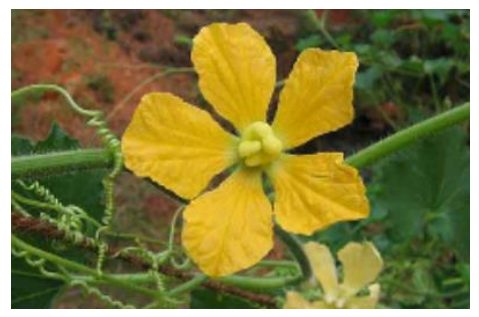

Figure 5. Gundur Flower
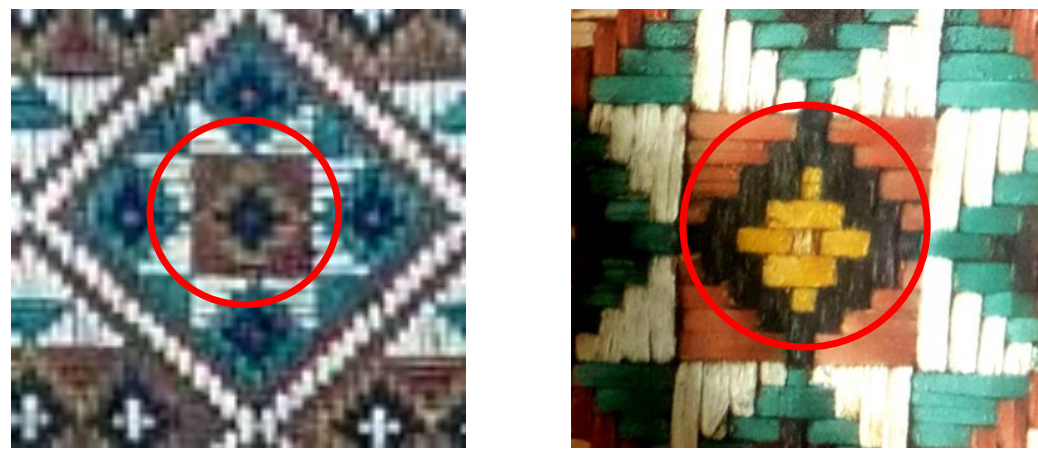

Figure 6. The Second Pattern at Ayo-Ayo's Karo Traditional House

At decoration pattern, this Gundur flower is placed repeatedly and forms a vertical line representing the upper world. There are two floral patterns that still look intact in the traditional house Karo's roof, located at the lower part with a black center, and gradually change its color into yellow to the top part of it. According to Jakob Sumardjo (2014), yellow represents the upper world while black represents the underworld. If seeing a different flower pattern based on the color in the middle, then the life meaning is increasingly going 'up' to the 'cleaner' and holier (figure 7). Another form of Gundur stilt formed on the Ayo-Ayo is the third pattern called Gundur Sitelenen which functions not only as a misfortune repellent, but also as a sign of luck for the families who live in the house (figure 8). 


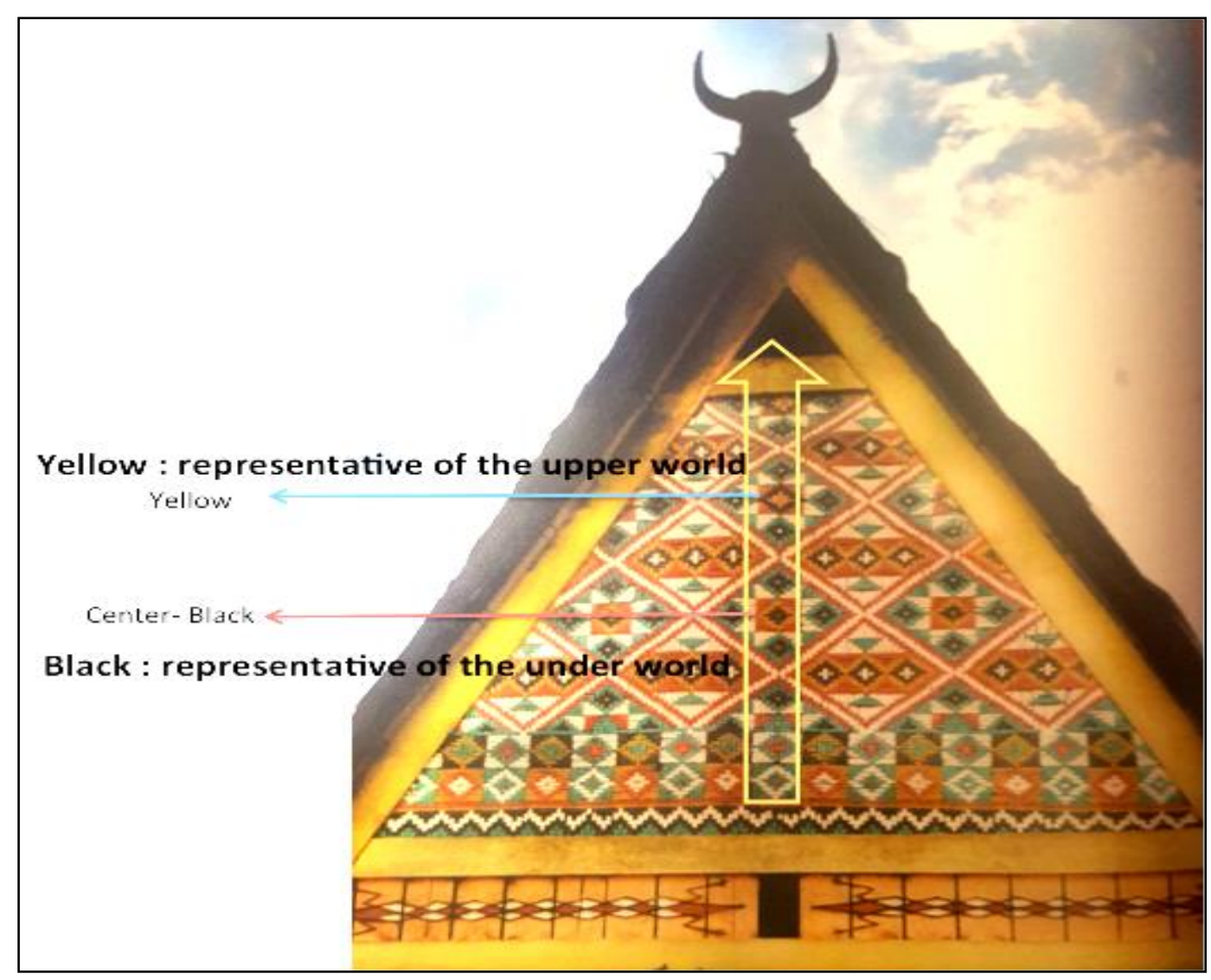

Figure 7. Gundur Flower Vertical Lines

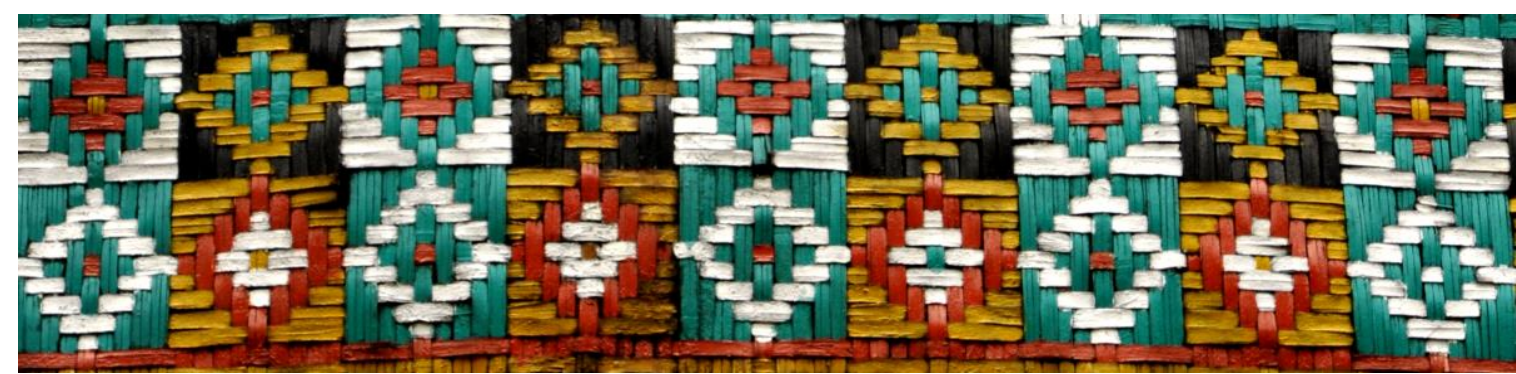

Figure 8. Third Pattern - Gundur Sitelenen Flower

The fourth pattern at the 'head' of the Karo traditional house is located at the bottom of the Ayo-Ayo, near the 'body' of the house. The fourth pattern is called Pancung-Pancung Cekala, representing bamboo shoots. The bamboo shoot stilation resembles triangular shape and on this fourth pattern, the triangular shape is horizontally repeated, representing human life as well as other living things in the middle world (figure 9). This motif as the underworld symbol is characterized by the dominant black color and green color application that 'wraps' the white color symbolizing the eternal upper world. This motif is functioning as a 'bridge' that connects the upper world and the underworld. The expression of the upper world and underworld relations is a life harmonization (figure 10). In the book Aesthetics Paradox written by Jakob Sumardjo, such motifs do mean a harmonious life, with the hope that the residents of Karo's house will have a harmonious life. 


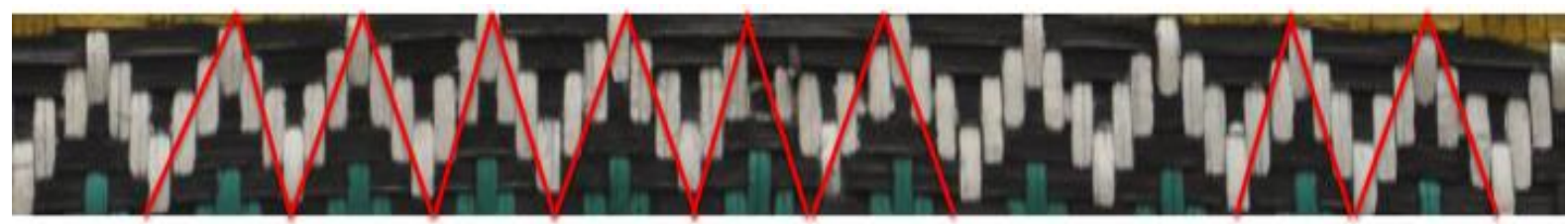

Figure 9. The fourth pattern - Pancung-Pancung Cekala

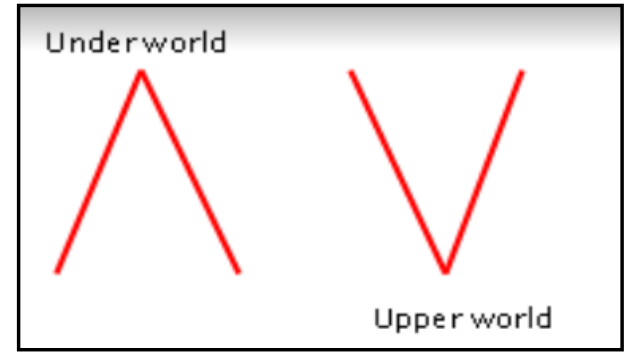

Figure 10. Stilation Meaning of Bambo Shoot Pattern - Upper World and Underworld

The fifth pattern is called as a cover pattern on the 'head' of the house, located at the bottom of the Ayo-Ayo. In contrast to previous patterns that was derived from natural plants, this pattern has a shape that resembles a lizard with its two heads located on the right and left ends of the body called the pengretret. The pengretret is considered as a mystical beast symbolizing strength, a guardian against demons or bad influence from the outside of the house and a family unifyer at the same time (figure 11).

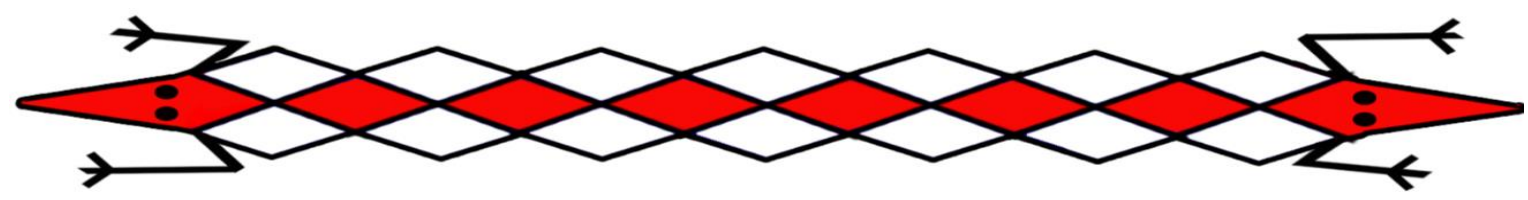

Figure 11. Fifth Pattern - Pengretret at Ayo-Ayo's Karo Traditional House Roof

\section{Conclusion}

The aesthetic element contained on the roof of Karo traditional house in Desa Lingga is simple. Overall, it has only one whole pattern. The intact pattern is a collection of vertical and horizontal lines forming geometric planes equipped with appropriate color settings. However, the whole pattern is actually composed of several meaningful elements. The meaning is based on the ideology of Karo society that closely relates to the life of the Karo tribe. These meanings can be seen based on Jakob Sumardjo's theoretical approach of "pattern", ie pattern two, pattern three and pattern four. Based on the motif on the roof of Karo's house, it can be discovered that the Karo tribe has three different archetypes, namely the pattern of two, three and four on the roof of Karo traditional house.

Pattern two was created from pattern "one" then created pattern three and evolved into pattern four. Pattern two is characterized by contradictory words, such as horizontal-vertical, top-down and right-left. It is also characterized by a horizontal line and vertical lines representing the upper and lower worlds. As can be seen in figure 10, pattern two emphasizes opposition rather than complementary. The third pattern was created as a 'harmonization' of both patterns. Pattern three are characterized by the 'middle world' on the beliefs of the Karo ethnic tradition, as the balance and bridge between the two other worlds, the upper as the sacred-heaven, whereas under is profane. Meanwhile, pattern four is well known in the culture of the peasant community that is held by the Karo people. Pattern four are found in rhombic motifs that have four ribs as symbols of ribs and 'life' 
angles, such as sky, land, sea and mountain and north (upstream), south (downstream), west, east. These patterns are representation of cosmology as well as a protector for the Karo community.

Based on the above issue, it can be concluded that Karo traditional house exists due to its richness of philosophy in its aesthetic element. This is evidence that cultural heritage is not only visible or tangible but also intangible. This finding is expected to make a positive contribution that enriches the world of education. Additionally, it may serve as one step in terms of preservation of Indonesian culture.

\section{References}

Adimihardja. Kusnaka. (2004). Arsitektur dalam Bingkai Kebudayaan. Hawthome: Foris Pub.

Bennet, Tony. (1998). Culture: A Reformer'sScience. London: SAGE Publications.

Dept. Pendidikan dan Kebudayaan RI. (1992). Arsitektur Tradisional Batak Karo. Jakarta: Dept. Pendidikan dan Kebudayaan RI.

Dept Pendidikan dan Kebudayaan RI. (1997). Arsitektur Tradisional Daerah Sumatera Utara. Jakarta: Dept Pendidikan Dan Kebudayaan RI.

Fauzi, Jufli. (2013). Makna Simbol Pengretret Rumah Adat Batak Karo. Bandung: Universitas Komputer Indonesia (UNIKOM). tidak dipublikasikan.

Flick, Uwe. (2009). An Introduction to Quaitative Research. Thousand Oaks, CA: SAGE Publications.

Sumardjo, Jakob. (2014). Estetika Paradoks. Bandung: Penerbit Kelir. 